\title{
Rollerblading over the Past: A Deconstruction of a Sociohistorical City Space
}

\author{
Mark T. S. Currie \\ University of Ottawa
}

\begin{abstract}
:
Positioning rollerblading as a form of walking, I critically reflect on my experience rollerblading to work in downtown Toronto. I never questioned whose land these roads were covering, what it meant that I could read all of the street names, nor my feelings of unconditional belonging as a Mixed-Race, White-passing, English-literate man. In this paper, I argue that everyday elements of the cityscape (re)shaped a racist sociohistorical geography and my place within it. I employ as a framework Hall's (1980) concept of articulation, Stanley's (2011) understanding of racisms as exclusions, and Puwar's (2004) concept of somatic dissonance. Through this lens, I deconstruct how my act of rollerblading exemplified the banality of the sociohistorical city space and unknowingly enacted the dominance of Whiteness.
\end{abstract}

Keywords: sociohistorical spaces; repeated representation; racism; banality of Whiteness; somatic disorientation/reorientation 


\section{Patiner sur le passé : une déconstruction d'un espace urbain sociohistorique}

\section{Résumé :}

Considérer le patin à roues alignées comme une forme de marche, je réfléchis de manière critique à mon expérience du roller pour travailler au centre-ville de Toronto. Je ne me suis jamais demandé à qui appartenaient la terre sous ces routes, ni le fait que je pouvais lire tous les noms de rues, ni mes sentiments d'appartenance inconditionnelle en tant qu'homme de race mixte, qui passait pour un Blanc et alphabétisé anglais. Dans cet article, je soutiens que des éléments quotidiens du paysage urbain ont (re)façonné une géographie sociohistorique raciste et ma place en son sein. J'emploie comme cadre d'analyse le concept d'articulation de Hall (1980), la compréhension des racismes comme exclusions de Stanley (2011) et le concept de Puwar (2004) de la dissonance somatique. À travers cette lunette, je déconstruis comment mon acte de patiner a illustré la banalité de l'espace sociohistorique de la ville et a incarné sans le savoir la domination de la blancheur.

Mots clés : les espaces sociohistoriques; la représentation répétée; le racisme; la banalité de la blancheur; la désorientation/réorientation somatique 


\section{Rollerblading to Work}

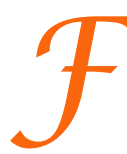

rom 2012 to 2013, I worked in Toronto in an office building at the intersection of Dundas

Street West and University Avenue. On spring and summer days, provided it was not raining,

I put on shorts and a t-shirt, packed my satchel with my lunch and office-wear, and

rollerbladed approximately three kilometers from my apartment six major blocks east and three north of the office building. I rolled along the paved roads, turning right and left through the grid pattern, crossing streets such as Jarvis and Yonge, cutting through Ryerson University campus, moving westward along Edward Street, connecting with University Avenue and turning left toward my destination one street south.

My rollerblading was a sort of "walking-on-wheels" engagement with space, as opposed to a literal walking. Rollerblading has similarities to walking-being upright on two feet with the coordinated movement of the body propelling me in directions I choose to travel-but the limitations of where rollerblades can be used offer a form of attunement with the environment around and under me, which can be but is not always recognized in non-wheeled walking. Contemplating my rollerblading forced me to consider the material that structured and marked the route I traveled, all indicative of humans at work, but humans not always in harmony with the earth. Unpacking my act of rollerblading required considerations for how the earth was covered over, who decided to make it this way, and the effects on how and which people use(d) the space.

It had never dawned on me to historicize or examine critically the work being done by the structur(e/ing) of the streets, the pavement on which I traveled and the signs repeatedly marking the territory. However, being present in a space without understanding the space, or without being on guard to justify my presence, stems from how I (did not) read the space and how I became read in the space. I identify as Mixed-Race. My father identifies as White and my mother as Coloured, which is a racialization unique to South Africa-her country of birth — where she was considered a secondclass in the country's Apartheid-era racial hierarchy. People sometimes racialize me as "not White", asking, "So, where are you from?" or even more invasively, "So, what are you?", but mostly people racialize me as White. As such, I am rarely asked to explain my presence in settler-colonial settings. Although I now feel I should have, I was not at that time triggered to consider myself in relation to the space in which I rollerbladed. I never questioned whose land the pavement covered, what it meant that I could read street names, or my feelings of unconditional belonging as a White-passing, English-literate man.

Nearly a decade later, and now researching relationships between public pedagogies, sociohistorical geographies, and racisms and anti-racisms, I have ontological understandings for investigating my rollerblading and what I took for granted within the city space. My reflection was triggered by the 2017 book Steal Away Home, by Karolyn Smardz Frost. The book presents a biography of Cecilia Reynolds, a racialized Black woman who escaped American enslavement and made a home in a Toronto neighbourhood that has since been erased, buried under the very 
pavement on which I rollerbladed. The more I investigated the past of my commuting path, the more I learned about historic communities of Black, Indigenous and People of Colour (BIPOC) in the space. I began to wonder how these histories were erased from the space and how I was able to occupy that space without recognizing the tools of erasure.

In this paper, I argue that everyday elements of the cityscape were erasing racialized histories, (re)shaping a racist sociohistorical geography and my place within it. I employ a lens that brings together Hall's (1980) concept of articulation, where varying markings and signs work togetherarticulate-to (re)assert dominant meanings; Stanley's (2011) understanding of racisms as exclusions of racialized people or groups that result in negative consequences for the people excluded; and Puwar's (2004) concept of somatic dissonance, where particular bodies are understood as "different" from the "norm". Through this lens, I examine how different spaces and positions "have historically been 'reserved' for specific [White male] kinds of bodies" (Puwar, 2004, p. 144) in order to understand how the "disorientation and consequent reorientation" (p. 18) of racialized bodies from sociohistorical spaces occurs. Placing myself within such a sociohistorical space, I deconstruct how my act of rollerblading exemplified the banality of the sociohistorical city space and unknowingly enacted dominance of Whiteness.

\section{The Past of My Commuting Path}

"Whiteness" is not a suggestion that all people identified as White are actively racist, intentionally targeting, excluding and harming BIPOC. Some White people are actively racist; many are not, yet participate in and benefit from systems founded on racisms. Whiteness is a term that does not relate to any sort of essence of being racialized as White, and rather refers to historically based systemic and societal structures that position White-specifically English-speaking White-as dominant, while the inclusion of BIPOC is conditional. Whiteness makes the racialization of white "the standard against which all other races are measured or valued [ $\cdots$ and] is the norm against which constructed racial differences become meaningful" (Kobayashi, et al., 2011, p. 5). Moreover, "if white normativity is integral to the formulation of historical and contemporary forms of racism, its power lies in its unequal capacity to naturalize its geography" (Kobayashi et al., 2011, p. 6). The ways a geography_a space given meaning through relationships between people and material—is structured and marked, and who has the power to make structures and markings official, contributes to dominant meanings of which bodies belong (or not) in a social space.

The city space in which I commuted is now known as "Old Toronto", referring to where the city was claimed as York by the British in 1793. Little did I know, part of this area was formerly known as The Ward. Torontonians understood The Ward as framed by College Street and Queen Street West (north to south), and Yonge Street and University Avenue (east to west), matching political boundaries drawn in 1853 for the municipal riding of St. John's Ward. It was perceived by many who lived elsewhere as a slum of poor immigrants (Lorinc et al., 2015). While some residents were financially poor, others, such as business owners, physicians and teachers, maintained stable, though 
not always affluent, professions. There are, however, few remaining representations of these people, rich or poor. Instead, official markers of White British colonialism remain dominant.

Names of streets around and within The Ward are written using the modernized Roman alphabet (Upward \& Davidson, 2011), posting English or anglicized words and names at each intersection. Turn by turn, street by street, I could locate myself because I am literate in the colonizer's language that maps the city. I did not wonder why or how English became the official language of the sociohistorical space; the signs articulated (with) each other and I read them as the way they have always been (Hall, 1980). In an examination of Toronto's (post)colonial street naming, Casagranda (2013) states that

because of their administrative functions, odonyms [street names] tend to be more or less stable over the years in order not to create confusion or ambiguity. As a consequence, their discursive components tend to fossilise as the "story" they tell crystallises in time and space. (p. 293)

The repeated street signs reassert English as dominant, confirming ownership and belonging for those who recognize English as their language, and supporting English as timeless, permanent and public. Kumashiro (2002) argues that repetition of particular symbols can be oppressive by causing marginalized identities "to experience, again and again, the privileging of only certain ways of identifying, thinking, or relating to others" (p. 68). Languages besides English are represented today in The Ward, but the representations are contained, as with individual restaurant signs, often paired with an English translation, and engaged without the same perceived certainty of permanence as with street name signs. English, then, is understood as the public's language, supposedly representing all citizens, and accessible to all; other languages are conditionally present. English as the official language perpetuates Whiteness not only because of the exclusionary effects its dominant and official use has on other languages and the varyingly racialized people who speak them, but also because names on English-language signs predominantly represent and commemorate White colonial bodies. This sort of dominance erases histories of racialized communities on the land of The Ward. These histories and the racialized people they represent are now "disoriented" (Puwar, 2004) and excluded (Stanley, 2011) from the space by the normalization of Whiteness.

\section{Histories Erased From the Space}

To understand how Whiteness became dominant in The Ward, I trace the history of the space back to before The Ward existed and look at how the land was colonized such that The Ward could be created. The Mississaugas of the Credit First Nation are the traditional keepers of the land the British colonized, named York in 1793, and then incorporated as Toronto in 1834. In 1787, the Mississaugas agreed to the Toronto Purchase, which the British believed sold them control of the land. However, the Mississaugas of the Credit "did not believe that land could be 'sold', or that their rights to use land and access resources for food and living, could be absolutely and permanently signed away" (Mississaugas of the New Credit First Nation [MNCFN], 2018, p. 13). They also "believed 
their lands were held in common, unlike the settlers who believed in the individual ownership of land" (MNCFN, 2018, p. 13). One year after York was founded, the British realized the agreement lacked a land description, making it void. After the British and the Mississaugas discussed corrections in 1805, the revised version, Toronto Purchase Treaty 13, re-confirmed the agreement, but "with a surreptitious increase in the amount of land surrendered" to the British (Freeman, 2010, p. 24). The British understood that they purchased just less than four million acres, leaving the Mississaugas approximately 200 acres and forcing them to repeatedly negotiate with colonial government for access to fishing waters (MNCFN, 2018, p. 13).

Over time, as the Mississaugas attempted to adapt to changing physical and social spaces of their territory, it became "increasingly clear that the community would have to relocate to an area less directly disturbed by Euro-Canadian settlement" (p. 14). As the history goes, "in 1847 the Mississaugas accepted an offer from the Six Nations to establish a new settlement on a tract of land situated in the southwest portion of the Six Nations Reserve" (p. 14) in southern Ontario. The relationships with the land by which the Mississaugas lived are not present in the ways Toronto is now structured. The Mississaugas' histories, however, are not the only histories paved over by Whiteness within Toronto and, more specifically, The Ward.

Researchers of The Ward commonly describe the historic Black community as consisting largely of freedom seekers and free Black people who fled the United States to escape enslavement (see Henry, 2018; Lorinc et al., 2015; Smardz Frost, 2017). Henry (2018) states that the "Town of York censuses from between 1797 and 1808 counted 13 enslaved Black men, women, and children owned by provincial administrator Peter Russell, provincial secretary and registrar William Jarvis, and Solicitor General Robert Gray", so there was a Black population in York prior to The Ward, but not in such an identifiable neighbourhood geography as would be later formed in The Ward. When the British Slavery Abolition Act came into force August 1, 1834, slavery in Canada ended, drawing in more freedom seekers. Shadd et al. (2005) state that "on first arrival, former slaves and free Black immigrants often boarded with families in St. John's Ward" (p. 33). Within a little over a decade after the Act, Black people in Toronto owned houses and neighbourhood businesses, and worked in various professions - much of the stuff of an established community. By the mid-1850s, with approximately 500 Black people living in The Ward-estimated as half the Black population of Toronto at that time (Henry, 2018) — the neighbourhood was host to celebratory and musical events to fundraise aid for freedom seekers and anti-slavery work (Smardz Frost, 2015, p. 69).

After the American Civil War ended in 1865, thereby abolishing legal slavery in the United States, some former freedom seekers in The Ward returned to the country that once held them in bondage. In the latter years of the 19th century, some remaining Black residents relocated to other areas of Toronto. Markings of the historic Black community of The Ward are minimal, "disorienting" Black bodies from the sociohistorical space (Puwar, 2004). The erasure of histories of Black people lends to understanding Black bodies as new, when the presence of Black bodies in The Ward, Toronto and Canada is actually longstanding. During a July 2018 episode of CBC Ideas with Kyle Brown, Afua Cooper stated that "to be Black in Canada includes always being ready to justify your 
existence in any given time and place". Meanwhile, the presence of white-looking bodies, as Maynard (2017) contends, is taken for granted. Beyond the histories of the Black community, there are yet more racialized histories of The Ward that Whiteness erases from the space.

For the first two decades of the $20^{\text {th }}$ century, The Ward was also home to a Jewish community, with a peak population in 1912 between 15,000 and 18,000 people (Levine, 2014), making living space quite compact. The initial Jewish residents were East European Jews (Murdie \& Teixeira, 2000), but, as John McAree wrote in a May 1912 MacLean's article, "The streets [of The Ward] swarm[ed] with old Jews and young, flashily dressed young Jews in the latest Queen Street styles, and patriarchal old Jews in gabardine and skull cap" (p. 18). As Murdie and Teixeira (2000) declare, The Ward "became a self-contained Jewish community with a high degree of institutional completeness in terms of its cultural, religious, and educational facilities, as well as Jewish businesses serving the needs of the community" (p. 7).

Historically, Jews were a targeted group when Toronto discourse turned to the causes of the city's ills. As "Jewish" was seen as a "race" unto itself, many White citizens of British birth or background found Jews to be disruptive of their visions for a "White Canada Forever" (Levine, 2014). Jewish children experienced bullying at school, and violent assaults and neighbourhood vandalism occurred against the Jewish community in The Ward. Despite these attacks, the Jewish community did not crumble and sought even more to solidify their place within Toronto (Levine, 2014). Although a recognized Jewish community remained in The Ward until around 1920, between 1912 and 1915, in response to overcrowding, a significant number of Jewish residents and businesses moved westward to Kensington Market. As the Jewish community moved outside The Ward, a new Chinese community developed in The Ward, seeking the same community support and shelter from racism as the Black and Jewish communities before them.

While many Jewish residents were moving out of The Ward, many of the nearly 2000 Chinese people in the city were moving in (Chan, 2011), creating a defined community after years of interrupted efforts to do so in other locations. Known as Toronto's first Chinatown, until the mid-to late-1960s (Chan, 2011), the Chinese community was centered by Elizabeth Street. As Chan (2011, p. 35) describes, attempts to develop a Chinese community space started south of The Ward on York Street and then moved to the southern edge of The Ward on Queen Street West between York Street and Elizabeth Street, all before landing on Elizabeth Street. Each attempt was interrupted and mostly short-lived, displacing the residents due to city calls for redevelopment. The Ward became the most solid of the neighbourhood establishment attempts.

Similar to the Black community of The Ward a little over a half-century earlier, Chinatown was a core space to the Chinese population. With more Chinese people coming to live in Toronto, the neighbourhood was where people made their homes and other community businesses, as well as community and political organizations (Chan, 2011). The creation of Chinatown not only provided a community to which Chinese people felt they belonged, it also supported the residents and businesses facing anti-Chinese laws, policies and actions. 
Chan (2011, p. 27) cites former Canadian Prime Minister John A. MacDonald addressing Parliament: "I do not think that it would be to the advantage of Canada or any other country occupied by Aryans for members of the Mongolian race to become permanent inhabitants." The federal government imposed a Head Tax requiring every Chinese person who landed in Canada from 1885 to 1923 to pay an entry fee (\$50 in 1885; $\$ 100$ in 1900; $\$ 500$ in 1903) and carry a proof-ofpayment certificate (Chan, 2011). The tax to exist in the space called Canada was not the only barrier people racialized as Chinese battled.

While the position of Chinatown in The Ward was more firmly established and remained in place longer than previous community-building attempts, it, too, felt government exclusion. In the 1940s, the municipal government began expropriating land from Chinese families and businesses for the eventual construction of present-day City Hall and Nathan Phillips Square, which was completed in 1965 and is now a concrete space that commonly serves as a community venue for concerts, winter skating and cultural celebrations. In 1967, the "Save Chinatown" campaign was led by Chinatown residents and business owners endeavouring to stop the city from conquering what had endured as Chinatown. Although the city did not actively displace the remaining residents, the community was fractured. The location of Chinatown shifted with many of the Chinese population relocating to what is Toronto's current Chinatown, running north-south along Spadina Avenue from College Street to Queen Street West and east-west along Dundas Street West from Beverly Street to Augusta Avenue. Once again, despite setting down roots, it was the Chinese community that just so happened to be where city development needed to take place.

By continuously displacing the Chinese community, the city (re)creates Chinese presence as new, repeatedly positioning them as temporary. Today, there are numerous generations of racialized Chinese people in Toronto who are made to feel that they do not unconditionally belong, in part because histories that give them claim to the city's past are erased by the concrete of towering buildings and the pavement that surrounds them. In building Toronto's City Hall and Nathan Phillips Square, markers of historic Chinese presence were paved over and replaced by markers and systems that perpetuate the dominance of Whiteness through possession of the land (Moreton-Robinson, 2015).

I expect critics might contend mobility and mortality of people, suggesting historic bodies are not erased through racism, but relocated as part of life changes. They might highlight that there are not enough streets, buildings or greenspace for every person of the past to have a commemoration and the low number of markers for BIPOC is merely logistics, not racism. They may also argue that no laws specifically bar anyone of any racialization from entering the space that was The Ward, and claim belonging in that space is a choice, rather than racist inclusions and exclusions reserving spaces predominantly for white bodies (Puwar, 2004). I can agree with these points only insofar far as the fact that people are not present in a space forever and not everyone can have a commemoration. The City of Toronto, however, maintains the names and images of a particularly White, English history through official and repeated markers such as streets, named after British colonizers, signs using English and anglicized language, and even the grid structure of the streets, designed under 
British colonial rule. White bodies of the past have also disappeared from the space, just like the historic Mississaugas, Black, Jewish and Chinese peoples, but Whiteness remains marked while BIPOC are erased from the social meanings of the present-day space that was The Ward.

Today, the distinction of the neighbourhood is largely erased, and only people researching the area's past seem to still use the name "The Ward". When the space stopped being recognized as "The Ward" is uncertain. Researchers suggest the label decreased in use and became replaced with other names as residents relocated and neighbourhood structures (e.g., businesses, places of worship, houses) were demolished and replaced with space-dominating edifices like government buildings and a shopping center (Toronto Ward Museum, 2020). On those days of commuting to work in 2012 and 2013, I never considered myself as rollerblading through "The Ward", because I did not know the histories. Because of my unrecognized relationship to Whiteness, I did not need to know the histories. I could engage with the sociohistorical space in banal-comfortable, unconditional, everyday-ways, as if I simply belonged.

\section{Reading Myself in a City Built by and for Dominance}

In reflecting on my times rollerblading through the section of the city that was The Ward, I recognize the banal dominance and exclusionary effects of Whiteness, and how my rolling travel exemplified this in the sociohistorical space. I examine how I understood myself to belong within the streets of The Ward. I am not a member of the Mississaugas of the Credit First Nation, do not racialize myself as Black, Jewish or Chinese, and have no personal history in or even around The Ward; yet, I never questioned and was never questioned by others about my belonging there. That I never felt the need to justify my occupation of the space, that I always felt sure of my ability to read the markings to navigate my way, that I did not feel the historic names around me to be affronts to my belonging in the space, and that I utilized but did not problematize the material control over the land, are all enactments of Whiteness in my everyday actions (Moreton-Robinson, 2015).

On my rollerblade to work, no one ever questioned if I spoke English or told me to go back where I came from; nor did police officers that I passed ever stop me without cause to question my White-passing appearance in the space, as countless BIPOC have experienced (for examples and discussion, see Cole, 2015; Ibrahim, 2004; Maynard, 2017). Maynard (2017) posits that "the ability to walk freely in public space is something that is taken for granted by most white Canadians" (p. 89). I now recognize and admit that in my experiences on those days while I rollerbladed, I modeled what Maynard (2017) describes, and my White-passing appearance allowed me to take for granted, my right to travel in those streets. I was aware of racisms perpetrated by the police, but did not fear entering public spaces that included police presence. I felt no need to qualify my being in the space or have an explanation in mind in case I was stopped. My lack of concern for being excluded from the space I traveled through on my way to work was part of my White privilege that stems from not only how I appear to others, but also my ability to read the street signs that repeated at each intersection and articulated (with) other signs' meanings (Hall, 1980). 
When I rolled across Jarvis Street, I read but did not recognize the racism of the street name. William Jarvis and his son Samuel were politicians in the Upper Canada government based in York, but also enslaved six Black people, and Samuel Jarvis embezzled approximately $£ 4000$ from First Nations groups (Errett, 2016). Next, I took a shortcut through Ryerson University campus, passing signs and buildings emblazoned with the Ryerson name. I passively engaged with, but did not actively disrupt the commemorations of Egerton Ryerson, who outlined justifications for the Indian Residential School system that kidnapped Indigenous children from their homes before forcing them into so-called education institutions that often subjected them to physical, psychological, sexual and emotional abuse. Then crossing over Yonge Street, I did not know that the Upper Canada Lieutenant-Governor John Graves Simcoe named the street after then-British Secretary of War Sir George Yonge, who, according to a Yonge Street plaque, was an expert of Roman roads and allocated British military regiments to York as protection from American attack. As Smith (2017) suggests, the street name honours rather than questions authority of colonial British military presence and control over the land. Crossing Yonge Street entailed entering the space that was once The Ward, but I did not recognize the erasure of the neighbourhood. The city-imposed structural and population changes of The Ward, especially in comparison to the stability of the Yonge Street name, along with the many other settler colonizer names, "acts as a reminder of British [read White] normalcy" (Smith, 2017, p. 41).

These are only three of countless examples of markers I passed while rolling through the streets, but they illustrate how design of the city space reserves space for and makes unconditional the presence of White, commonly male, colonizer bodies (Puwar, 2004). The street signs and building names articulate (Hall, 1980) a history of settler colonizers, making colonizers' history dominant in the downtown space. I did not see the names of the Black bodies that built those streets (Winks, 1997). I did not see the Mississaugas' name for the area of Toronto, "Wonscotonach", an Anishinaabemowin word translated as "Back Burnt Grounds" or "Burning Bright Point" (MNCFN, 2018 , p. 3). The name of the city, Toronto, does derive from the Mohawk word "tkaronto", which translates to "where there are trees standing in the water" (Levine, 2014, p. 8); however, this name was anglicized for the English tongue (Casagranda, 2013) and comes from the language of an Indigenous nation whose territory is outside of Toronto, so the city's name is not even honouring the keepers of that land - the Mississaugas of the Credit. Casagranda (2013) reminds us that more European-sounding names were "given to what was nameless for the European explorer" (p. 291), and by imposing names to places that were already named, the Mississaugas' history and presence becomes buried-sometimes literally_under a colonial project of development. Guided by the English and anglicized street names that contribute to erasure, I unknowingly rolled right over these pasts.

Even if street signs were changed to Anishinaabemowin, Yiddish, Mandarin, or any of the many other languages spoken in Toronto, there is one feature of the space that would continue to mark the presence of Whiteness, and it actually allowed me to rollerblade as conveniently as I did. Toronto streets are predominantly structured in a grid formation, creating limitations and forms of control 
over where, how and even which people experience city spaces (Grant, 2001). The paved grid of streets was convenient for my rollerblading to work, and I did not consider the convenience as something I would not have had if the streets were not paved or set on a grid. While Grant (2001) acknowledges that the grid structure does have advantages of simplicity, replicability, legibility and ease of physical access, she concludes that "the grid clearly signifies that planners were at work. It denies spontaneity and indigenous [sic] landscape traditions. It imposes a rational conceptual order that transcends time and space and proclaims the control and power of central authorities" (p. 237). Whiteness is cemented into the city geography that was designed by colonizing powers.

The grid design of the streets that became lined by towering buildings and warranted traffic signs and lights materializes understandings of space being governed and owned in the publicprivate binary that started with colonialism. So-called public lands are not "held in common". Streets, sidewalks, traffic laws and zoning regulations designate how these spaces are to be used as forms of property, and, as history shows, who is permitted to use them. I, however, rollerbladed on the pavement through the grid while following the signs leading me to a privately owned office property, all without feeling conditions placed on my presence.

\section{Conclusion}

Upon arriving at the office building, I sat on a concrete ledge, removed my rollerblades, passed through the building doors, stepped onto the elevator and rode to the $11^{\text {th }}$ floor where I changed into my office-wear and began work. I did not think about how or why my travel was without systemic barriers, or whose place in the space was conditional or "reserved" (Puwar, 2004). The repetition of and articulation between (Hall, 1980) spatial markers made them appear banal, yet maintained dominating meanings of Whiteness, allowing me to read myself and be read by others as unconditionally belonging. Now, contemplating rollerblading allows me to ponder my relationships with everyday human-imposed material that enabled me to travel as I did, and that erases (Stanley, 2011) histories of BIPOC communities. Now understanding my relationship with the space as more complex than mere commuting, I see anti-racist possibilities.

I recognize that some markers of Whiteness will remain, at least for now, as the removal of more seemingly permanent features such as the grid structure and skyscrapers is unlikely. Street names and languages represented, however, are markers that are becoming more immediate starting points of change. Additionally, although more complex than changing signs, systemic racisms that force BIPOC to qualify and justify their presence can be quashed through system restructuring. Overall, though, engagement with sociohistorical spaces is relational, suggesting people can and should reflect on their normal(ized) actions in everyday spaces, what they take for granted, and what includes and excludes them. I embrace my Mixed-Race identity and work to develop my anti-racist efforts and, in reflecting on my rollerblading, I see the need to honestly and sometimes uncomfortably critique my understanding of myself in relation to Whiteness. Learning histories of racialized communities in The Ward helped me see the city in new ways and shake the 
stability of Whiteness by triggering me to question and critique how and why I feel I belong (or not) in that space.

\section{Acknowledgement}

The author would like to gratefully acknowledge the support of SSHRC as well as his supervisor, Dr. Timothy J. Stanley.

\section{About the Author}

Mark Currie is a PhD candidate and educator in the Faculty of Education, University of Ottawa. He focuses his research on public pedagogies, sociohistorical spaces and enacting anti-racisms. His doctoral research examines how the Ontario Black History Society's walking tour in downtown Toronto acts as an educational tool for engaging and (re)shaping sociohistorical spaces as anti-racist geographies.

\section{References}

Brown, K. G. (2018, July 5). Slavery's long shadow: The impact of 200 years enslavement in Canada. CBC Radio Ideas. https://www.cbc.ca/radio/ideas/slavery-s-long-shadow-the-impact-of-200years-enslavement-in-canada-1.4733595

Casagranda, M. (2013). From Empire Avenue to Hiawatha Road: (Post)colonial naming practices in the Toronto street index. In O. Felecan (Ed.), Proceedings of the International Conference on Onomastics "Name and Naming" (Vol. 2, pp. 291-302). https://onomasticafelecan.ro /iconn2/proceedings/3_06_Casagranda_Mirko_ICONN_2.pdf

Chan, A. (2011). The Chinese in Toronto from 1878: From outside to inside the circle. Dundurn.

Cole, D. (2015, April 21). The skin I'm in: I've been interrogated by police more than 50 times-all because I'm black. Toronto Life. https://torontolife.com/city/life/skin-im-ive-interrogatedpolice-50-times-im-black/

Errett, J. (2016, May 7). Was Jarvis street named after a city-builder, or a slave-owner? Prepare for a debate. CBC News. https://www.cbc.ca/news/canada/toronto/jarvis-street-slavery-1.3564667

Freeman, V. (2010). "Toronto has no history!": Indigeneity, settler colonialism, and historical memory in Canada's largest city. Urban History Review/Revue d'histoire urbaine, 38(2), 21-35. https://doi.org/10.7202/039672ar

Grant, J. L. (2001). The dark side of the grid revisited: Power and urban design. In R. Rose-Redwood \& L. Bigon. (Eds.), Gridded worlds: An urban anthology (pp. 75-100). Springer.

Hall, S. (1980). Race, articulation, and societies structured in dominance. In UNESCO (Ed.), Sociological theories: Race and colonialism (pp. 305-345). UNESCO.

Henry, N. (2018, August 1). Freedom abound: Celebrating Emancipation Day in St. John's Ward, 1845-1860. Spacing. http://spacing.ca/toronto/2018/08/01/freedom-abound-celebratingemancipation-day-in-st-johns-ward-1845-1860/ 
Ibrahim, A. (2004). One is not born Black: Becoming and the phenomenon(ology) of race. Philosophical Studies in Education, 35(1), 77-87. http://ovpes.org/wpcontent/uploads/2012 101/ibrahim2004.pdf

Kobayashi, A., Cameron, L., \& Baldwin, A. (Eds.). (2011). Rethinking the great white north: Race, nature, and the historical geographies of whiteness in Canada. University of British Columbia Press.

Kumashiro, K. (2002). Against repetition: Addressing resistance to anti-oppressive change in the practices of learning, teaching, supervising, and researching. Harvard Educational Review, 72(1), 67-92. https://vula.uct.ac.za/access/content/group/25f04c1d-1bf4-497a-bdb5e12357b066ef/Test/Kumashiro\%20-\%20Against\%20Repetition.pdf

Levine, A. (2014). Toronto: Biography of a city. Douglas \& MacIntyre.

Lorinc, J., McClelland, M., Sheinberg, E., \& Taylor, T. (Eds.). (2015). The Ward: The life and loss of Toronto's first immigrant neighbourhood. Coach House Books.

Maynard, R. (2017). Policing Black lives: State violence in Canada from slavery to present. Fernwood. Mississaugas of the New Credit First Nation. (2018). The Mississaugas of the Credit: Historical territory, resource and land use. http://mncfn.ca/wp-content/uploads/2018/08/TheMississaugas-of-the-Credit-Historical-Territory-Resource-and-Land-Use.pdf

Moreton-Robinson, A. (2015). The white possessive: Property, power, and Indigenous sovereignty. University of Minnesota Press.

Murdie, R. A., \& Teixiera, C. (2000). Towards a comfortable neighbourhood and appropriate housing: Immigrant experiences in Toronto. Center of Excellence for Research on Immigration and Settlement. http://ceris.ca/wp-content/uploads/virtual-library/Murdie_et_al_2000.pdf

Puwar, N. (2004). Space invaders: Race, gender and bodies out of place. Berg.

Shadd, A., Cooper, A., \& Smardz Frost, K. (2005). The underground railroad: Next stop, Toronto! Natural Heritage Books.

Smardz Frost, K. (2017). Steal away home: One woman's epic flight to freedom-and her long road back to the south. Harper Collins.

Smith, B. (2017). Cartographies of colonial commemoration: Critical toponymy and historical geographies in Toronto. Journal of the Canadian Association for Curriculum Studies, 15(2), 34 47. https://jcacs.journals.yorku.ca/index.php/jcacs/article/view/40297/36286

Stanley, T. J. (2011). Contesting white supremacy: Schoo/ segregation, anti-racism, and the making of Chinese Canadians. University of British Columbia Press.

Toronto Ward Museum. (2020). About the Ward. http://www.wardmuseum.ca/picturingtheward/ theward/

Upward, C., \& Davidson, G. (2011). The history of English spelling. Wiley-Blackwell.

Winks, R. W. (1997). The Blacks in Canada: A history (2 ${ }^{\text {nd }}$ ed.). McGill-Queen's University Press. 